\title{
Antibacterial Compounds in Predominant Trees in Finland: Review
}

\section{Sari Metsämuuronen ${ }^{1}$ and Heli Siren ${ }^{2 \star}$}

${ }^{1}$ Lappeenranta University of Technology, PO Box 20, FI-53851 Lappeenranta, Finland

${ }^{2}$ Department of Chemistry, University of Helsinki, PO Box 55, Fl-00014 University of Helsinki, Finland

\begin{abstract}
The extracts of Scots pine, Norway spruce, silver and white birches stem, bark, roots, leaves and needles contain several useful bioactive compounds that exhibit antibacterial activity against pathogens. Both phenolic extracts and essential oils are bacteriostatic against several bacteria. The main individual antibacterial phenolic compounds in Scots pine are pinosylvins that effectively inhibit growth of pathogens such as Bacillus cereus, Staphylococcus aureus and Listeria monocytogenes. From other phenolic compounds lignans appeared to be the least bacteriostatic and flavonoids tend to occur as glycosylated forms which have lower antibacterial activity than their aglycones. Gram-positive bacteria are generally more susceptible to plants bioactive compounds than gram-negative bacteria.
\end{abstract}

Keywords: Antibacterial compounds; Norway spuce; Extract; Hydrolysis; Fermentation

\section{Introduction}

Plants synthesise low molecular mass compounds, phytoalexins, which protect them against attacks by fungi, bacteria and insects $[1,2]$. Several studies of these plants used as traditional folk medicine have recently been published [3-10]. Interest in natural bioactive compounds has arisen for their multiple biological effects, including antioxidant, antifungal and antibacterial activity. The potential use of these compounds in food preservation and pharmaceutical applications as oxidants and for cancer chemoprevention has been investigated $[1,11,12]$. Their potential use against pathogenic microorganisms and infections that are currently difficult to treat because of the resistance that microorganisms have built against antibiotics would be one interesting application. Essential oils and phenolic extracts have been tested against multi-drug-resistant human pathogens and intestinal bacteria, like methicillin-resistant Staphylococcus aureus (MRSA) [8,13-19].

Essential oils are very complex natural mixtures which can contain about 20-60 components at quite different concentrations [20]. They are characterised by two or three major components at fairly high concentrations (20-70\%) compared to others components present in trace amounts. The main group is composed of terpenes and terpenoids.

The main groups of bioactive phenolic compounds in plants are simple phenols and phenolic acids, stilbenes, flavonoids and lignans, which are derivatives of phenylpropanoid metabolism via the shikimate and acetate pathways $[11,12,21,22]$. These secondary metabolites are often bound to a mono- or oligosaccharide or to uronic acid [2]. The saccharide or uronic acid part is called glycone and the other part the aglycone. Flavonoids, phenolic acids, stilbenes, tannins and lignans are especially common in leaves, flowering tissues and woody parts such as stems and barks. In bark and knots they are especially important defence against microbial attack after injury. Hence, the bark and knot extracts have been observed to be more active against bacteria than the wood extracts [23]. The effectiveness of the defence varies among plant species. The long-lived and slow growing plants have been observed to be more active than the fast growing ones [24].

The aim of this literature review is to clarify the antibacterial compounds present in the predominant tree species in Finland, Scots pine (Pinus sylvestris), Norway spruce (Picea abies), silver birch (Betula pendula) and white birch (Betula pubescens). The extraction of these valuable compounds from forest biomass is of special interest as they are available in different wood harvesting and industrial residues, such as bark, knots, stump and roots.

\section{Phenolic Compounds}

The bioactive compounds are present in wood and, thus, they can be solubilised by different solvents [12]. In published studies phenolic compounds have been most often obtained through ethanol, methanol or acetone extraction as alone or after hexane extraction (Table 1). The most frequently used method to determine the total phenols in the extracts is colorimetric measurement with the Folin-Ciocalteu reagent. However, this reagent may react with any reducing substances other than phenols and therefore measures the total reducing capacity of a sample. By this method total phenol content is expressed in terms of gallic acid (GAE) or tannic acid (TAE) equivalents. The individual components have been identified by using gas (liquid) chromatography (GC, GLC) and mass spectrometry (MS) or high-performance liquid chromatography (HPLC).

The evaluation methods for antibacterial activity can be divided into diffusion, dilution and optical density methods. The most commonly used screen to evaluate antimicrobial activity is the agar diffusion technique. In this method, the diameter of inhibition zone is measured at the end of incubation time. The usefulness of diffusion method is limited to the generation of preliminary data only [25]. With respect to that, the activity values are not comparable, since the studies are made with different procedures and chemicals. Thus, extracts, extraction methods, assess of antimicrobial activity and strains of test organisms vary in the publications.

The minimal inhibiting (MIC) and bactericidal (MBC) concentrations are defined as the lowest concentrations of tested

${ }^{*}$ Corresponding author: Heli Siren, University of Helsinki, Department of Chemistry, PO Box 55, FI-00014 University of Helsinki, Finland, Tel: 358-29415010; E-mail: heli.m.siren@helsinki.fi, helimmsiren@gmail.com

Received June 04, 2014; Accepted July 04, 2014; Published July 12, 2014

Citation: Metsämuuronen S, Siren H (2014) Antibacterial Compounds in Predominant Trees in Finland: Review. J Bioprocess Biotech 4: 167 doi 10.4172/2155-9821.1000167

Copyright: ( 2014 Metsämuuronen S, et al. This is an open-access article distributed under the terms of the Creative Commons Attribution License, which permits unrestricted use, distribution, and reproduction in any medium, provided the original author and source are credited. 
Citation: Metsämuuronen S, Siren H (2014) Antibacterial Compounds in Predominant Trees in Finland: Review. J Bioprocess Biotech 4: 167 doi: 10.4172/2155-9821.1000167

Page 2 of 13

\begin{tabular}{|c|c|c|c|c|c|}
\hline $\begin{array}{l}\text { Tree } \\
\text { species }\end{array}$ & Part & $\begin{array}{l}\text { Drying method, Solvent } \\
\text { extraction }\end{array}$ & Compounds & Identificatio & Ref. \\
\hline \multirow[t]{14}{*}{ Scots pine } & heartwood & $\begin{array}{l}\text { Oven-dried } 60^{\circ} \mathrm{C}, 48 \mathrm{~h}, \\
80 \% \text { acetone }\end{array}$ & Total phenolics $6.7-13.6 \mathrm{mg} \mathrm{TAE}^{\mathrm{g}-1}$ & $\begin{array}{l}\text { Folin- } \\
\text { Ciocalteau }\end{array}$ & [26] \\
\hline & heartwood & Oven-dried $60^{\circ} \mathrm{C} 48 \mathrm{~h}$, acetone & $\begin{array}{l}\text { Total pinosylvins } 4.7-7.5 \mathrm{mg}^{\mathrm{g}-1} \\
\text { Pinosylvin, PMME, PDME }\end{array}$ & GLC-MS & [26] \\
\hline & heartwood & $\begin{array}{l}\text { Oven-dried } 60^{\circ} \mathrm{C} 48 \mathrm{~h}, \\
80 \% \text { acetone }\end{array}$ & Total phenolics 4.55-4.66 mg TAE $\mathrm{cm}^{-1}$ & Folin-Ciocalteu & {$[27]$} \\
\hline & heartwood & Oven-dried $60^{\circ} \mathrm{C} 48 \mathrm{~h}$, acetone & Pinosylvin, PMME and PDME $2.07-3.16 \mathrm{mg} \mathrm{cm}^{-1}$ & GLC-MS & [27] \\
\hline & knotwood & $\begin{array}{l}\text { Freeze-dried } \\
\text { 1. hexane } \\
\text { 2. acetone:water }\end{array}$ & $\begin{array}{l}\text { pinosylvin, PMME, DHPMME chromatographic } \\
\text { purification, } \\
\text { chrystallization }\end{array}$ & GC after & [28] \\
\hline & knotwood & $\begin{array}{l}\text { Freeze-dried, } \\
\text { 1. Hexane } \\
\text { 2. Acetone }\end{array}$ & $\begin{array}{l}\text { Nortrachelogenin fractionated by } \\
\text { flash chromatography }\end{array}$ & GC-MS & {$[29,30]$} \\
\hline & knotwood & $\begin{array}{l}\text { N.a., } \\
\text { 1. Hexane } \\
\text { 2. Acetone/water }(95: 5)\end{array}$ & Lingnans, stilbenes and flavonoids & GC-FID & {$[30]$} \\
\hline & knotwood & $\begin{array}{l}\text { N.a., } \\
\text { 1. hexane } \\
\text { 2. acetone }\end{array}$ & $\begin{array}{l}\text { Pinosylvin, PSME Fractionation } \\
\text { by flash chromatography }\end{array}$ & GC-MS & {$[30]$} \\
\hline & $\begin{array}{l}\text { knotwood, } \\
\text { bark }\end{array}$ & $\begin{array}{l}\text { Freeze-dried, } \\
\text { 1. Hexane } \\
\text { 2. Acetone }\end{array}$ & $\begin{array}{l}\text { Pinosylvin } \\
\text { Fractionation using flash } \\
\text { chromatography }\end{array}$ & $\begin{array}{l}\text { GC-FID } \\
\text { HPSEC }\end{array}$ & [31] \\
\hline & knotwood & $\begin{array}{l}\text { Resin } \\
\text { Methyl-tert-butyl ether }\end{array}$ & $\begin{array}{l}\text { Pinoresinol } \\
\text { Purification with flash chromatography }\end{array}$ & $\begin{array}{l}\text { GC-FID } \\
\text { HPSEC }\end{array}$ & [31] \\
\hline & phloem & Freeze/vacuum dried, $80 \%$ methanol & & & [32] \\
\hline & $\begin{array}{l}\text { phloem, } \\
\text { bark }\end{array}$ & $\begin{array}{l}\text { Air-dried } \\
1 . \\
2 .\end{array}$ & $\begin{array}{l}22 \text { phenolic compounds } \\
70 \% \text { acetone } \\
\text { Chloroform }\end{array}$ & $\begin{array}{l}\text { HPLC-DAD } \\
\text { HPLC-ESI- } \\
\text { MS }\end{array}$ & [33] \\
\hline & $\begin{array}{l}\text { needle, cork, } \\
\text { bark }\end{array}$ & $\begin{array}{l}\text { Air dried, } \\
80 \% \text { methanol }\end{array}$ & Phenolics & $\begin{array}{l}\text { Folin- } \\
\text { Ciocalteau }\end{array}$ & [34] \\
\hline & needles & Distillation & Essential oil (mainly terpenes and terpenoids) & GC & [35] \\
\hline \multirow[t]{4}{*}{$\begin{array}{l}\text { Norway } \\
\text { spruce }\end{array}$} & $\begin{array}{l}\text { knotwood } \\
\text { bark }\end{array}$ & $\begin{array}{l}\text { 1. Hexane } \\
\text { 2. Acetone/water (95:5) }\end{array}$ & Lingnans, stilbenes and flavonoids & GC-FID & [30] \\
\hline & knotwood & $\begin{array}{l}\text { Freeze-dried, } \\
\text { 1.Hexane } \\
\text { 2. Acetone/water }(95: 5)\end{array}$ & Hydroxymatairesinol & GC-MS & [30] \\
\hline & phloem & Freeze-dried, $80 \%$ ethanol & Isorhapontin, astringin, piceid & GC-MS & {$[37]$} \\
\hline & phloem & Freeze-dried, $80 \%$ methanol & $\begin{array}{l}\text { Isorhapontin, astringin, piceid, } \\
\text { taxifolin gulcoside, }(+) \text {-catechin }\end{array}$ & HPLC & [38] \\
\hline \multirow[t]{2}{*}{ Silver birch } & bark & $\begin{array}{l}\text { 1. Hexane } \\
\text { 2. Acetone/water }(95: 5)\end{array}$ & Lingnans, stilbenes and flavonoids & GC-FID & {$[30]$} \\
\hline & phloem, bark & Air dried, $80 \%$ methanol & Phenolics & Folin-Ciocalteau & [34] \\
\hline
\end{tabular}

$\mathrm{ASE}=$ accelerated solvent extractor, DHPMME = dihydropinosylvin monomethyl ether, FID = flame ionization detector, PDME = pinosylvin dimethyl ether $\mathrm{PMME}=$ pinosylvin monomethyl ether, $\mathrm{TAE}=$ tannic acid equivalent

Table 1: Extraction and identification methods of antibacterial substances.

compounds which completely inhibited bacterial growth and which results in more than $99.9 \%$ killing of the bacteria being tested, respectively. The MIC and MBC have been determined by the liquid dilution method.

\section{Scots pine}

Antioxidant, antifungal and antibacterial [26-34] activity of phenolic extracts of Scots pine growing in Finland have been investigated during the last decades. In most of these studies activity of knotwood extracts were detected and heartwood extracts were detected only against brown-rot fungus. The total phenolic concentration has been observed to vary a lot between the different parts of the tree: 76.0, 17.5 and $1.1 \mathrm{mg} \mathrm{GAE} \mathrm{g}^{-1}$ for dried bark, needles and cork, respectively [35-38]. For the heartwood the total phenolic concentration of 4.55$4.66 \mathrm{mg} \mathrm{TAE} \mathrm{cm}^{-3}$ of wood [27] and 6.7-13.6 mg TAE $\mathrm{g}^{-1}$ wood [26] have been reported. Willför et al. [39] reported that in knotwood, the amount of extractable phenolic compounds can be as large as $10 \%$ $(\mathrm{w} / \mathrm{w})$, which was several times more than that they observed in the stem wood.

Knotwood extracts containing lignans, stilbenes and flavonoids have been observed to show antibacterial activity against some pathogenic bacteria [30] (Table 2). The strongest inhibition has been observed against the gram-positive pathogenic bacteria Bacillus cereus, $S$. aureus and Listeria monocytogenes, while inhibition against the gram-negative bacteria Escherichia coli, and Pseudomonas fluorescens was only slight. The extract did not show any inhibitory effect on Lactobacillus plantarum and Salmonella infantis. Also the phoem extracts of Scots pine have shown to be clearly active against $S$. aureus, but not against $E$. coli [32]. The hydrophilic extracts from knotwood of several pines, rich in stilbenes, proved to be efficient antibacterial agents when tested against paper mill bacteria Burkholderia multivorans, Bacillus coagulans and Alcaligenes xylosoxydans [28].

The main components in hydrophilic extracts of Scots pine have 
Citation: Metsämuuronen S, Siren H (2014) Antibacterial Compounds in Predominant Trees in Finland: Review. J Bioprocess Biotech 4: 167 doi: 10.4172/2155-9821.1000167

Page 3 of 13

\begin{tabular}{|c|c|c|c|c|}
\hline Tree species & Bacteria & Activity & Method & Ref. \\
\hline $\begin{array}{l}\text { Scots pine, } \\
\text { knotwood }\end{array}$ & $\begin{array}{l}\text { Escherichia coli } \\
\text { Salmonella infantis } \\
\text { Pseudomonas fluorescens } \\
\text { Bacillus cereus } \\
\text { Staphylococcus aureus } \\
\text { Listeria monocytogenes } \\
\text { Lactobacillus plantarum }\end{array}$ & $\begin{array}{l}5 \pm 13 \% \\
0 \pm 4 \% \\
13 \pm 2 \% \\
79 \pm 3 \% \\
30 \pm 23 \% \\
47 \pm 20 \% \\
0 \pm 3 \%\end{array}$ & $\begin{array}{l}\text { Well } \\
\text { microplates } \\
\text { and turbidity } \\
\text { reader }\end{array}$ & [30] \\
\hline $\begin{array}{l}\text { Scots pine, } \\
\text { knotwood extract }\end{array}$ & $\begin{array}{l}\text { Burkholderia multivorans } \\
\text { Bacillus coagulans } \\
\text { Alcaligenes xylosoxydans }\end{array}$ & $\begin{array}{l}\text { strong, > } 20 \mathrm{~mm} \\
\text { strong, > } 20 \mathrm{~mm} \\
\text { moderate, 16-19 mm }\end{array}$ & $\begin{array}{l}\text { Agar } \\
\text { diffusion }\end{array}$ & [28] \\
\hline $\begin{array}{l}\text { Scots pine, } \\
\text { phloem }\end{array}$ & $\begin{array}{l}\text { Escherichia coli } \\
\text { Staphylococcus aureus }\end{array}$ & $\begin{array}{l}\text { slight, } 1-3 \mathrm{~mm} \\
\text { clear, } 4-10 \mathrm{~mm}\end{array}$ & $\begin{array}{l}\text { Cylinder } \\
\text { diffusion }\end{array}$ & [32] \\
\hline $\begin{array}{l}\text { Norway spruce, } \\
\text { knotwood }\end{array}$ & $\begin{array}{l}\text { Burkholderia multivorans } \\
\text { Bacillus coagulans } \\
\text { Alcaligenes xylosoxydans }\end{array}$ & $\begin{array}{l}0 \\
0 \\
\text { small, } 11-15 \mathrm{~mm}\end{array}$ & $\begin{array}{l}\text { Agar } \\
\text { diffusion }\end{array}$ & [28] \\
\hline $\begin{array}{l}\text { Norway spruce, } \\
\text { knotwood and } \\
\text { bark }\end{array}$ & $\begin{array}{l}\text { Escherichia coli } \\
\text { Salmonella infantis } \\
\text { Pseudomonas fluorescens } \\
\text { Bacillus cereus } \\
\text { Staphylococcus aureus } \\
\text { Listeria monocytogenes } \\
\text { Lactobacillus plantarum }\end{array}$ & $\begin{array}{l}0 \\
0 \\
\text { knotwood } 38 \% \text {, bark } 0 \% \\
\text { knotwood } 15 \% \text {, bark } 0 \% \\
0 \\
0 \\
0\end{array}$ & $\begin{array}{l}\text { Well } \\
\text { microplates } \\
\text { and turbidity } \\
\text { reader }\end{array}$ & [30] \\
\hline $\begin{array}{c}\text { Norway spruce, } \\
\text { needles }\end{array}$ & $\begin{array}{l}\text { Escherichia coli } \\
\text { Staphylococcus aureus }\end{array}$ & $\begin{array}{l}0 \\
\text { slight, } 1-3 \mathrm{~mm}\end{array}$ & $\begin{array}{l}\text { Cylinder } \\
\text { diffusion }\end{array}$ & [32] \\
\hline $\begin{array}{l}\text { Silver birch, } \\
\text { knotwood }\end{array}$ & $\begin{array}{l}\text { Burkholderia multivorans } \\
\text { Bacillus coagulans } \\
\text { Alcaligenes xylosoxydans }\end{array}$ & $\begin{array}{l}0 \\
0 \\
\text { small, } 11-15 \mathrm{~mm}\end{array}$ & & [28] \\
\hline $\begin{array}{l}\text { Silver birch, } \\
\text { knotwood and } \\
\text { bark }\end{array}$ & $\begin{array}{l}\text { Escherichia coli } \\
\text { Salmonella infantis } \\
\text { Pseudomonas fluorescens } \\
\text { Bacillus cereus } \\
\text { Staphylococcus aureus } \\
\text { Listeria monocytogenes } \\
\text { Lactobacillus plantarum }\end{array}$ & $\begin{array}{l}0 \\
0 \\
\text { knotwood } 20 \% \text {, bark } 22 \% \\
\text { knotwood } 14 \% \text {, bark } 0 \% \\
0 \\
0 \\
0\end{array}$ & $\begin{array}{l}\text { Well } \\
\text { microplates } \\
\text { and turbidity } \\
\text { reader }\end{array}$ & [30] \\
\hline White birch, leaf & $\begin{array}{l}\text { Escherichia coli } \\
\text { Staphylococcus aureus }\end{array}$ & $\begin{array}{l}\text { slight, } 1-3 \mathrm{~mm} \\
\text { clear, } 4-10 \mathrm{~mm}\end{array}$ & $\begin{array}{l}\text { Cylinder } \\
\text { diffusion }\end{array}$ & [32] \\
\hline
\end{tabular}

$\mathrm{MBC}=$ minimal bactericidal concentration, $\mathrm{MIC}=$ minimal inhibiting concentration

Table 2: Antibacterial activity of wood extracts and essential oils against selected bacteria.

been observed to be stilbenes, lignans (31\%) nortrachelogenin being the most abundant lignan (30\%) and oligolignans (6\%) [31]. In the heartwood of the brown-rot fungus resistant and susceptible trees, the average total stilbenes concentration $6.4-7.5 \mathrm{mg} \mathrm{g}^{-1}$ and $4.7-5.0 \mathrm{mg} \mathrm{g}^{-1}$ of dry weight, respectively, have been measured [26].

Stilbenes (Figure 1) are 1,2-diarylethenes, the A ring usually having two hydroxyl groups in the $\mathrm{m}$-position, while $\mathrm{B}$ ring is substituted by hydroxy and methoxy groups in the o-, $\mathrm{m}$ - and/or p-positions [11]. Stilbenes are synthesised mainly by forest trees [12], in monomeric form and as dimeric, trimeric and polymeric stilbenes, the so-called viniferins. They are commonly found in the roots, barks, rhizomes and leaves [11]. The most abundant stilbenes in Scots pine extracts are pinosylvins: $38 \%$ in knotwoods [31] and 6-7\% in heartwoods [27], whereas in the bark extracts they have not been found [40]. Pinosylvin and pinosylvin monomethyl ether (PMME) are the main pinosylvins, pinosylvin dimethyl ether (PDME) being less abundant $[26,28,31,41]$. Dihydropinosylvin monomethyl ether (DHPMME) has been isolated from Pinus strobus knotwood [30]. The pinosylvin-3-Omethyltransferase enzyme catalyses the conversion of pinosylvin to the monomethyl ether that plays a role in the resistance of the plant to stress including ozone and infection [41]. Hence, a high concentration of PMME relative to pinosylvin may be an indication of high stress levels of the trees.

The highest antimicrobial activities of the pure compounds present in Scots pine have been observed with pinosylvin and PMME, followed by DHPMME and flavanone pinocembrin [30] (Table 3). Very strong inhibition effects (62-100\%) have been observed against human pathogens B. cereus, $S$. aureus and L. monocytogenes. Pinosylvin, DHPMME, PMME and flavonoid pinocembrin (from P. cembra) have shown a very similar activity against bacteria as the Pinus extracts where they have been isolated [30]. Both Välimaa et al. [30] and Lindberg et al. [28] have observed that the antibacterial activity correlate with the stilbene content of the extracts and, hence, stilbenes have been concluded to be the main antibacterial compounds of hydrophilic extracts of Scots pine.

The precise mechanism of antibacterial action of stilbenes is unclear. One possibility is that they destroy the membrane structure resulting in burst of the cell [42]. Välimaa et al. [30] suggested that two hydroxyl groups in meta position in one of the aromatic rings and the double bond in the carbon chain between the rings may play an important role. From phenolic acids chlorogenic acid has shown stronger activity against $E$. coli than ferulic acid [43].

Flavonoids consist of a central three-ring structure (Table 4). Their activity is proposed to be due to their ability to complex with extracellular and soluble proteins and to complex with bacterial cell walls [1]. Flavonoids and oligomers of flavonoids and proanthocyanidins, frequently occur as glycosides [2]. Different flavonol glycosides are typical in pine needles and the sugar residues are found to be 
<smiles>[R2]c1cc([R1])cc(/C=C/c2ccc([R4])c([R3])c2)c1</smiles>

R1 R2

$\begin{array}{ll}\text { Pinosylvin } & \mathrm{R} 1 \\ \text { Pinosylvin monomethyl ether } & \mathrm{OH} \\ \text { Pinosylvin dimethyl ether } & \mathrm{OMe} \\ \text { Piceatannol } \\ \text { Resveratrol }\end{array}$

Piceasides, $\mathrm{R}=\mathrm{H}$ or $\mathrm{Me}[42]$

$\begin{array}{lll}\text { R2 } & \text { R3 } & \text { R4 } \\ \text { OH } & \text { H } & \text { H } \\ \text { OM e } & \text { H } & \text { H } \\ \text { OMe } & \text { H } & \text { H } \\ \text { OH } & \text { OH } & \text { OH } \\ \mathrm{OH} & \mathrm{H} & \mathrm{OH}\end{array}$

$\begin{array}{llll} & & & \text { Aglycones } \\ \mathrm{OH} & \mathrm{OH} & \mathrm{OH} & \text { Piceatannol } \\ \mathrm{OH} & \mathrm{H} & \mathrm{OH} & \text { Resveratrol } \\ \text { O-Glu } & \mathrm{OH} & \mathrm{OH} & \text { Isorhapontigenin }\end{array}$<smiles>[R7]c1cc([R1])cc(CCc2ccccc2)c1</smiles>

Dihydropinosylvin

Dihydropinosylvin monomethyl ether
R1 R2

$\mathrm{OH} \quad \mathrm{OH}$

$\mathrm{OH} \mathrm{OMe}$

Figure 1: Chemical structures of stilbenes and stilbenes glucosides found in conifers.

bonded mainly at the 3-position [28,44-48] (Appendix 1). However, the glycoside contents on other parts than needles are not available. Dihydro-flavonol type taxifolin and flavanone type pinocembrin were the main flavonoids in knotwood [29]. Pinocembrin has been observed to inhibit growth of several bacteria, the strongest activity being against B. cereus (Table 3).

Lignans isolated from knotwoods of conifers are strong antioxidants [29], but their antibacterial activity is observed to be low. Purified lignans (Figure 2), matairesinol, hydroxymatairesinol, lariciresinol and secoisolaricinol, have not shown activity against any of the tested bacteria and isolariciresinol and nortrachelogenin have shown slight activity only against B. cereus [30] (Table 3).

\section{Norway spruce}

The average amount of extractable phenolic compound in Norway spruce knotwood is around $15 \%(\mathrm{w} / \mathrm{w})$, but as high values as nearly $30 \%(w / w)$ have been detected [49]. The amount of phenolic compounds in the stem wood has been observed to be much lower, usually $0.15-0.3 \%$. Malá et al. [50] observed that in Norway spruce cells the soluble glycoside-bound forms of phenolic acids accounted for $\sim 85 \%$ of the total content, followed by the methanol-insoluble cell wall-bound phenolic esters (7-8\%). The amount of methanol soluble esters and free phenolic acids were low, accounting for $\sim 2$ and $4-5 \%$ of total phenolic contents, respectively [50]. Free, ester-bound (released after alkaline hydrolysis) and glycoside-bound (released after acid hydrolysis) phenolic acids were obtained from a methanol extract [50]. Two cinnamic acid derivatives, p-coumaric and ferulic acids and five benzoic acid derivatives (anisic, p-hydroxybenzoic, vanillic and syringic acids) were found in the Norway spruce cells. p-Hydroxybenzoic acid glucoside and native ferulic acid have been reported in the extracts of roots [51].

Several stilbenes and stilbenes glucosides have been detected in different parts of Norway spruce. Astringin and isorhapontin are the main constitutive stilbenes glycosides in Norway spruce $[36,37,50]$. Zeneli et al. [36] detected the contents of astringin and isorhapontin of 20.2 and $71.8 \%$ in sapwood phenolics and 38.8 and $46.5 \%$ in bark phenolics, respectively, in trees growing in Norway. Wood phenolics contained also $5.1 \%$ piceid and bark phenolics $7.7 \%$ piceid and $0.4 \%$ piceatannol. Viiri et al. [37] have detected stilbene glycoside concentration of $\sim 7-8 \mu \mathrm{g} \mathrm{mg}^{-1}$ in fresh phloem tissue. Over half of it was isorhapontin and rest astringin and piceid, while resveratrol was the most abundant aglycone $\left(\sim 0.5 \mu \mathrm{g} \mathrm{mg}^{-1}\right)$. These stilbenes aglycones and glucosides have been detected also in bark extracts [31]. In healthy phloem stilbenes typically occur as glycosides. Piceoside, piceatannol and its glucoside, isorhapontin have been detected in roots [51]. On the contrary, Willför et al. [49] have not found stilbenes in the hydrophilic knotwood extractives of Norway spruce. They reported that more than a half of the knotwood extracts are lignans, the rest being mainly oligolignans. The most abundant lignan was hydroxymatairesinol [29,31]. Its two isomers constitute over $70 \%$ of the lignans [29].

Shan et al. [45] evaluated antibacterial activity of resveratrol and its glucoside piceid against five bacteria (Table 3 ). In general, efficacy of aglycone and glucoside appeared to be almost the same. The MIC values of both compounds were $313-625 \mathrm{mg} \mathrm{L}^{-1}$ and in the case of L. monocytogenes MIC was also bacteriostatic concentration.

Needles have considerably high content of phenolic substances: $155.3 \mathrm{mg} \mathrm{GAE} \mathrm{g}^{-1}$ dry weight of the original sample [34]. Five types of flavonoids (flavones, flavonols, flavanones, dihydro-flavonols 
Citation: Metsämuuronen S, Siren H (2014) Antibacterial Compounds in Predominant Trees in Finland: Review. J Bioprocess Biotech 4: 167 doi: 10.4172/2155-9821.1000167

Page 5 of 13

\begin{tabular}{|c|c|c|c|c|c|}
\hline Substance class & Substance & Bacteria & Inhibitory effect, \% & Method & Ref. \\
\hline \multirow{3}{*}{ Hydroxy-cinnamic acid } & \multirow{2}{*}{$\begin{array}{l}\text { Ferulic acid } \\
\text { (commercial) }\end{array}$} & $\begin{array}{l}\text { Escherichia coli } \\
\text { Salmonella enterica } \\
\text { Enterococcus faecalis }\end{array}$ & $\begin{array}{l}\text { Slight } \\
\text { Slight } \\
\text { No inhibition }\end{array}$ & $\begin{array}{l}\text { Agar well } \\
\text { diffusion }\end{array}$ & [43] \\
\hline & & $\begin{array}{l}\text { Escherichia coli } \\
\text { Bacillus licheniformis } \\
\text { Micrococcus luteus }\end{array}$ & $\begin{array}{l}\text { MIC } 375 \mathrm{mg} \mathrm{L}^{-1} \\
\text { MIC } 375 \mathrm{mg} \mathrm{L}^{-1} \\
\text { MIC } 375 \mathrm{mg} \mathrm{L}^{-1}\end{array}$ & Not announced & [44] \\
\hline & $\begin{array}{l}\text { Chlorogenic acid } \\
\text { (commercial) }\end{array}$ & $\begin{array}{l}\text { Escherichia coli } \\
\text { Salmonella enterica } \\
\text { Enterococcus faecalis }\end{array}$ & $\begin{array}{l}\text { Clear } \\
\text { No inhibition } \\
\text { No inhibition }\end{array}$ & $\begin{array}{l}\text { Agar well } \\
\text { diffusion }\end{array}$ & [43] \\
\hline \multirow{13}{*}{ Stilbene } & \multirow[t]{2}{*}{$\begin{array}{l}\text { Pinosylvin } \\
\text { (Scots pine knotwood) }\end{array}$} & $\begin{array}{l}\text { Escherichia coli } \\
\text { Salmonella infantis } \\
\text { Pseudomonas fluorescens } \\
\text { Bacillus cereus } \\
\text { Staphylococcus aureus } \\
\text { Listeria monocytogenes } \\
\text { Lactobacillus plantarum }\end{array}$ & $\begin{array}{l}54 \pm 8 \\
42 \pm 20 \\
50 \pm 15 \\
101 \pm 6 \\
76 \pm 2 \\
62 \pm 15 \\
0 \pm 0\end{array}$ & $\begin{array}{l}\text { Well } \\
\text { microplates } \\
\text { and turbidity } \\
\text { reader }\end{array}$ & [30] \\
\hline & & $\begin{array}{l}\text { Burkholderia multivorans } \\
\text { Bacillus coagulans } \\
\text { Alcaligenes xylosoxydans }\end{array}$ & $\begin{array}{l}29-34 \mathrm{~mm} \\
21 \mathrm{~mm} \\
23 \mathrm{~mm}\end{array}$ & $\begin{array}{l}\text { Disc diffusion } \\
\text { and liquid } \\
\text { culture }\end{array}$ & [28] \\
\hline & \multirow[t]{2}{*}{$\begin{array}{l}\text { Pinosylvin monomethyl } \\
\text { ether (Scots pine } \\
\text { knotwood) }\end{array}$} & $\begin{array}{l}\text { Escherichia coli } \\
\text { Salmonella infantis } \\
\text { Pseudomonas fluorescens } \\
\text { Bacillus cereus } \\
\text { Staphylococcus aureus } \\
\text { Listeria monocytogenes } \\
\text { Lactobacillus plantarum }\end{array}$ & $\begin{array}{l}17 \pm 7 \\
40 \pm 7 \\
35 \pm 2 \\
92 \pm 4 \\
105 \pm 12 \\
100 \pm 7 \\
2 \pm 11\end{array}$ & $\begin{array}{l}\text { Well } \\
\text { microplates } \\
\text { and turbidity } \\
\text { reader }\end{array}$ & [30] \\
\hline & & $\begin{array}{l}\text { Burkholderia multivorans } \\
\text { Bacillus coagulans } \\
\text { Alcaligenes xylosoxydans }\end{array}$ & $\begin{array}{l}15-17 \mathrm{~mm} \\
18 \mathrm{~mm} \\
13 \mathrm{~mm}\end{array}$ & $\begin{array}{l}\text { Disc diffusion } \\
\text { and liquid } \\
\text { culture }\end{array}$ & [28] \\
\hline & \multirow[t]{2}{*}{$\begin{array}{l}\text { Dihydropinosylvin } \\
\text { monomethyl ether } \\
\text { (Scots pine knotwood) }\end{array}$} & $\begin{array}{l}\text { Escherichia coli } \\
\text { Salmonella infantis } \\
\text { Pseudomonas fluorescens } \\
\text { Bacillus cereus } \\
\text { Staphylococcus aureus } \\
\text { Listeria monocytogenes } \\
\text { Lactobacillus plantarum }\end{array}$ & $\begin{array}{l}18 \pm 2 \\
14 \pm 2 \\
22 \pm 6 \\
82 \pm 3 \\
76 \pm 4 \\
64 \pm 12 \\
1 \pm 1\end{array}$ & $\begin{array}{l}\text { Well } \\
\text { microplates } \\
\text { and turbidity } \\
\text { reader }\end{array}$ & [30] \\
\hline & & $\begin{array}{l}\text { Burkholderia multivorans } \\
\text { Bacillus coagulans } \\
\text { Alcaligenes xylosoxydans }\end{array}$ & $\begin{array}{l}20-23 \mathrm{~mm} \\
19 \mathrm{~mm} \\
13 \mathrm{~mm}\end{array}$ & $\begin{array}{l}\text { Disc diffusion } \\
\text { and liquid } \\
\text { culture }\end{array}$ & [28] \\
\hline & Resveratrol (C. baiaessi) & MRSA & $\mathrm{MIC}>128 \mathrm{mg} \mathrm{L}^{-1}$ & Liquid microdilution & [15] \\
\hline & \multirow{6}{*}{$\begin{array}{l}\text { Resveratrol } \\
\text { (commercial) }\end{array}$} & \multirow{2}{*}{ Escherichia coli } & \multirow{2}{*}{$\begin{array}{l}\text { MIC } 313 \mathrm{mg} \mathrm{L}^{-1} \\
\text { MBC } 625 \mathrm{mg} \mathrm{L}^{-1}\end{array}$} & Agar well & [45] \\
\hline & & & & diffusion & \\
\hline & & Salmonella anatum & $\begin{array}{l}\text { MIC } 313 \mathrm{mg} \mathrm{L}^{-1} \\
\text { MBC } 625 \mathrm{mg} \mathrm{L}^{-1}\end{array}$ & & \\
\hline & & Bacillus cereus & $\begin{array}{l}\text { MIC } 313 \mathrm{mg} \mathrm{L}^{-1} \\
\text { MBC } 2500 \mathrm{mg} \mathrm{L}^{-1}\end{array}$ & & \\
\hline & & Listeria monocytogenes & $\begin{array}{l}\text { MIC } 625 \mathrm{mg} \mathrm{L}^{-1} \\
\text { MBC } 625 \mathrm{mg} \mathrm{L}^{-1}\end{array}$ & & \\
\hline & & Staphylococcus aureus & $\begin{array}{l}\text { MIC } 313 \mathrm{mg} \mathrm{L}^{-1} \\
\text { MBC } 625 \mathrm{mg} \mathrm{L}^{-1}\end{array}$ & & \\
\hline \multirow[t]{5}{*}{$\begin{array}{l}\text { Stilbene } \\
\text { glucoside }\end{array}$} & \multirow{5}{*}{$\begin{array}{l}\text { Piceid } \\
\text { (commercial) }\end{array}$} & Escherichia coli & $\begin{array}{l}\text { MIC } 625 \mathrm{mg} \mathrm{L}^{-1} \\
\text { MBC } 1250 \mathrm{mg} \mathrm{L}^{-1}\end{array}$ & \multirow{5}{*}{$\begin{array}{l}\text { Agar well } \\
\text { diffusion }\end{array}$} & \multirow{5}{*}[45]{} \\
\hline & & Salmonella anatum & $\begin{array}{l}\text { MIC } 313 \mathrm{mg} \mathrm{L}^{-1} \\
\text { MBC } 313 \mathrm{mg} \mathrm{L}^{-1}\end{array}$ & & \\
\hline & & Bacillus cereus & $\begin{array}{l}\mathrm{MIC}>2500 \mathrm{mg} \mathrm{L}^{-1} \\
\mathrm{MBC} 2500 \mathrm{mg} \mathrm{L}^{-1}\end{array}$ & & \\
\hline & & Listeria monocytogenes & $\begin{array}{l}\text { MIC } 625 \mathrm{mg} \mathrm{L}^{-1} \\
\text { MBC } 625 \mathrm{mg} \mathrm{L}^{-1}\end{array}$ & & \\
\hline & & Staphylococcus aureus & $\begin{array}{l}\text { MIC } 313 \mathrm{mg} \mathrm{L}^{-1} \\
\text { MBC } 625 \mathrm{mg} \mathrm{L}^{-1}\end{array}$ & & \\
\hline Flavone & Apigenin & $\begin{array}{l}\text { Escherichia coli } \\
\text { Salmonella enterica } \\
\text { Enterococcus faecalis }\end{array}$ & $\begin{array}{l}\text { No inhibition } \\
\text { No inhibition } \\
\text { No inhibition }\end{array}$ & $\begin{array}{l}\text { Agar well } \\
\text { diffusion }\end{array}$ & [43] \\
\hline Flavanone & $\begin{array}{l}\text { Pinocembrin } \\
\text { (Pinus cembra } \\
\text { knotwood) }\end{array}$ & $\begin{array}{l}\text { Escherichia coli } \\
\text { Salmonella infantis } \\
\text { Pseudomonas fluorescens } \\
\text { Bacillus cereus } \\
\text { Staphylococcus aureus } \\
\text { Listeria monocytogenes } \\
\text { Lactobacillus plantarum }\end{array}$ & $\begin{array}{l}15 \pm 2 \\
14 \pm 8 \\
7 \pm 3 \\
74 \pm 6 \\
30 \pm 9 \\
55 \pm 16 \\
4 \pm 5\end{array}$ & $\begin{array}{l}\text { Well } \\
\text { microplates } \\
\text { and turbidity } \\
\text { reader }\end{array}$ & [30] \\
\hline
\end{tabular}


Citation: Metsämuuronen S, Siren H (2014) Antibacterial Compounds in Predominant Trees in Finland: Review. J Bioprocess Biotech 4: 167 doi: 10.4172/2155-9821.1000167

Page 6 of 13

\begin{tabular}{|c|c|c|c|c|c|}
\hline \multirow[t]{7}{*}{ Flavonol } & $\begin{array}{l}\text { Quercetin, } 500 \mu \mathrm{g} \\
\text { (commercial) }\end{array}$ & $\begin{array}{l}\text { Escherichia coli } \\
\text { Pseudomonas aeruginosa } \\
\text { Micrococcus luteus } \\
\text { Bacillus subtilis } \\
\text { Staphylococcus aureus } \\
\text { Staphylococcus epidermis }\end{array}$ & $\begin{array}{l}\text { Slight-moderate } \\
\text { Slight } \\
\text { Moderate } \\
\text { Slight } \\
\text { Clear } \\
\text { Clear }\end{array}$ & $\begin{array}{l}\text { Hole-plate } \\
\text { diffusion }\end{array}$ & [32] \\
\hline & Quercetin & Staphylococcus aureus & MIC 2 mM & Hole-in-plate & [46] \\
\hline & Quercetin & $\begin{array}{l}\text { Escherichia coli } \\
\text { Salmonella enterica }\end{array}$ & No - clear & $\begin{array}{l}\text { Agar well } \\
\text { diffusion }\end{array}$ & [43] \\
\hline & $\begin{array}{l}\text { Isoguercitrin } \\
\text { (quercetin-3-glucoside) }\end{array}$ & $\begin{array}{l}\text { Escherichia coli } \\
\text { Salmonella enterica } \\
\text { Enterococcus faecalis }\end{array}$ & $\begin{array}{l}\text { No inhibition } \\
\text { No inhibition } \\
\text { No inhibition }\end{array}$ & $\begin{array}{l}\text { Agar well } \\
\text { diffusion }\end{array}$ & [43] \\
\hline & \multirow[t]{2}{*}{$\begin{array}{l}\text { Kaempferol, } \\
\text { (commercial) }\end{array}$} & $\begin{array}{l}\text { Escherichia coli } \\
\text { Micrococcus luteus } \\
\text { Bacillus subtilis } \\
\text { Staphylococcus aureus } \\
\text { Staphylococcus epidermis }\end{array}$ & $\begin{array}{l}\text { No activity } \\
\text { No activity } \\
\text { Slight } \\
\text { Clear } \\
\text { No activity }\end{array}$ & $\begin{array}{l}\text { Hole-plate } \\
\text { diffusion }\end{array}$ & [32] \\
\hline & & MRSA & MIC $25->400 \mathrm{mg} \mathrm{L}^{-1}$ & Agar dilution & [19] \\
\hline & Myricetin & $\begin{array}{l}\text { Escherichia coli } \\
\text { Salmonella enterica } \\
\text { Enterococcus faecalis }\end{array}$ & $\begin{array}{l}\text { Strong } \\
\text { No inhibition } \\
\text { No inhibition }\end{array}$ & $\begin{array}{l}\text { Agar well } \\
\text { diffusion }\end{array}$ & [43] \\
\hline \multirow[t]{2}{*}{ Flavanone } & & MRSA & MIC $200-400 \mathrm{mg} \mathrm{L}^{-1}$ & Agar dilution & [19] \\
\hline & $\begin{array}{l}\text { Naringenin } \\
\text { (commercial) }\end{array}$ & $\begin{array}{l}\text { Escherichia coli } \\
\text { Pseudomonas aeruginosa } \\
\text { Micrococcus luteus } \\
\text { Bacillus subtilis } \\
\text { Staphylococcus aureus } \\
\text { Staphylococcus epidermis }\end{array}$ & $\begin{array}{l}\text { Moderate-clear } \\
\text { Slight } \\
\text { Strong } \\
\text { Clear-strong } \\
\text { Strong } \\
\text { Strong }\end{array}$ & $\begin{array}{l}\text { Hole-plate } \\
\text { diffusion }\end{array}$ & [32] \\
\hline Flavan & Catechin & $\begin{array}{l}\text { Escherichia coli } \\
\text { Salmonella enterica } \\
\text { Enterococcus faecalis }\end{array}$ & $\begin{array}{l}\text { No inhibition } \\
\text { No inhibition } \\
\text { No inhibition }\end{array}$ & $\begin{array}{l}\text { Agar well } \\
\text { diffusion }\end{array}$ & [43] \\
\hline Tannins & Gallic acid & $\begin{array}{l}\text { Escherichia coli } \\
\text { Proteus mirabilis } \\
\text { Staphylococcus aureus } \\
\text { Staphylococcus epidermis } \\
\text { Staphylococcus haemolyticus }\end{array}$ & $\begin{array}{l}\text { MIC } 125 \mathrm{mg} \mathrm{L}^{-1} \\
\text { MIC } 62 \mathrm{mg} \mathrm{L}^{-1} \\
\text { MIC } 31 \mathrm{mg} \mathrm{L}^{-1} \\
\text { MIC } 31 \mathrm{mg} \mathrm{L}^{-1} \\
\text { MIC } 62 \mathrm{mg} \mathrm{L}^{-1}\end{array}$ & Disc diffusion & [47] \\
\hline \multirow[t]{2}{*}{ Lignans } & $\begin{array}{l}\text { Matairesinol } \\
\text { (synthesized), } \\
\text { Hydroxymatairesinol } \\
\text { (Norway spruce), } \\
\text { Lariciresinol } \\
\text { (balsam fir), } \\
\text { Secoisolariciresinol } \\
\text { (Brazilian pine) }\end{array}$ & $\begin{array}{l}\text { Escherichia coli } \\
\text { Salmonella infantis } \\
\text { Pseudomonas fluorescens } \\
\text { Bacillus cereus } \\
\text { Staphylococcus aureus } \\
\text { Listeria monocytogenes } \\
\text { Lactobacillus plantarum }\end{array}$ & $\begin{array}{l}0 \\
0 \\
0 \\
0 \\
0 \\
0 \\
0 \\
0\end{array}$ & $\begin{array}{l}\text { Well } \\
\text { microplates } \\
\text { and turbidity } \\
\text { reader }\end{array}$ & [30] \\
\hline & $\begin{array}{l}\text { Isolariciresinol, } \\
\text { Nortrachelogenin } \\
\text { (Scots pine knotwood) }\end{array}$ & $\begin{array}{l}\text { Escherichia coli } \\
\text { Salmonella infantis } \\
\text { Pseudomonas fluorescens } \\
\text { Bacillus cereus } \\
\text { Staphylococcus aureus } \\
\text { Listeria monocytogenes } \\
\text { Lactobacillus plantarum }\end{array}$ & $\begin{array}{l}0 \\
0 \\
0 \\
10-13 \\
0 \\
0 \\
0\end{array}$ & $\begin{array}{l}\text { Well } \\
\text { microplates } \\
\text { and turbidity } \\
\text { reader }\end{array}$ & [30] \\
\hline
\end{tabular}

MIC = minimal inhibiting concentration, MRSA = methicillin-resistant Staphylococcus aureus

Table 3: Pure antibacterial substances and their activity against selected bacteria.

and flavans [22]) occur in Norway spruce (Appendix 1). Several glycosides of quercetin, isorhamnetin, kaempferol, myricetin, lericitrin and syringetin have been found in needles of Norway spruce [52]. Glucose at the 3- or 7-position is the most common glycone part of the glycosides. However, majority of the antibacterial activity data concerns aglycones and only limited data on glyciosides are available. From these flavonoids aglycones quercetin [32,43,46], kaempferol $[19,32]$ and myricetin [43] have been observed to have antibacterial activity (Table 3), whereas quercetin-3-glucoside (quercitrin) [43] have been observed to be inactive. Silva [47] have reported that quercetin and myricetin-3-rhamnosides are inactive against Proteus mirabilis and $E$. coli at a concentration of $500 \mathrm{mg} \mathrm{L}^{-1}$ and against $S$. aureus, Staphylococcus epidermidis and Staphylococcus haemolyticus at a concentration of $350 \mathrm{mg} \mathrm{L}^{-1}$. It may be that glycosylation of flavonoids reduces their antibacterial activity when compared to corresponding aglycones.

\section{Betula genera}

Phloem of silver birch contains phenolics $85.5 \mathrm{mg} \mathrm{GAE} \mathrm{g}^{-1}$, but bark only $2.0 \mathrm{mg} \mathrm{GAE} \mathrm{g}^{-1}$ [34]. Kähkönen et al. [34] have found three different types of phenols in silver birch inner bark (phloem): arylbutanoid glycosides, benzoic acid derivatives and catechins, whereas Willför et al. [29] have found stilbene-derived compounds. Main phenolics in white birch and silver birch leaves have been identified by Ossipov et al. [53]. Chlorogenic acid constituted almost $50 \%$ of the phenolic content in white birch leaves, but in silver birch leaves only $5 \%$ of the total phenolic contents. (+)-Catechin and several quercetin, kaempferol and myricetin glycosides were the next abundant compounds identified (Appendix 1). 
Citation: Metsämuuronen S, Siren H (2014) Antibacterial Compounds in Predominant Trees in Finland: Review. J Bioprocess Biotech 4: 167 doi: 10.4172/2155-9821.1000167

Page 7 of 13

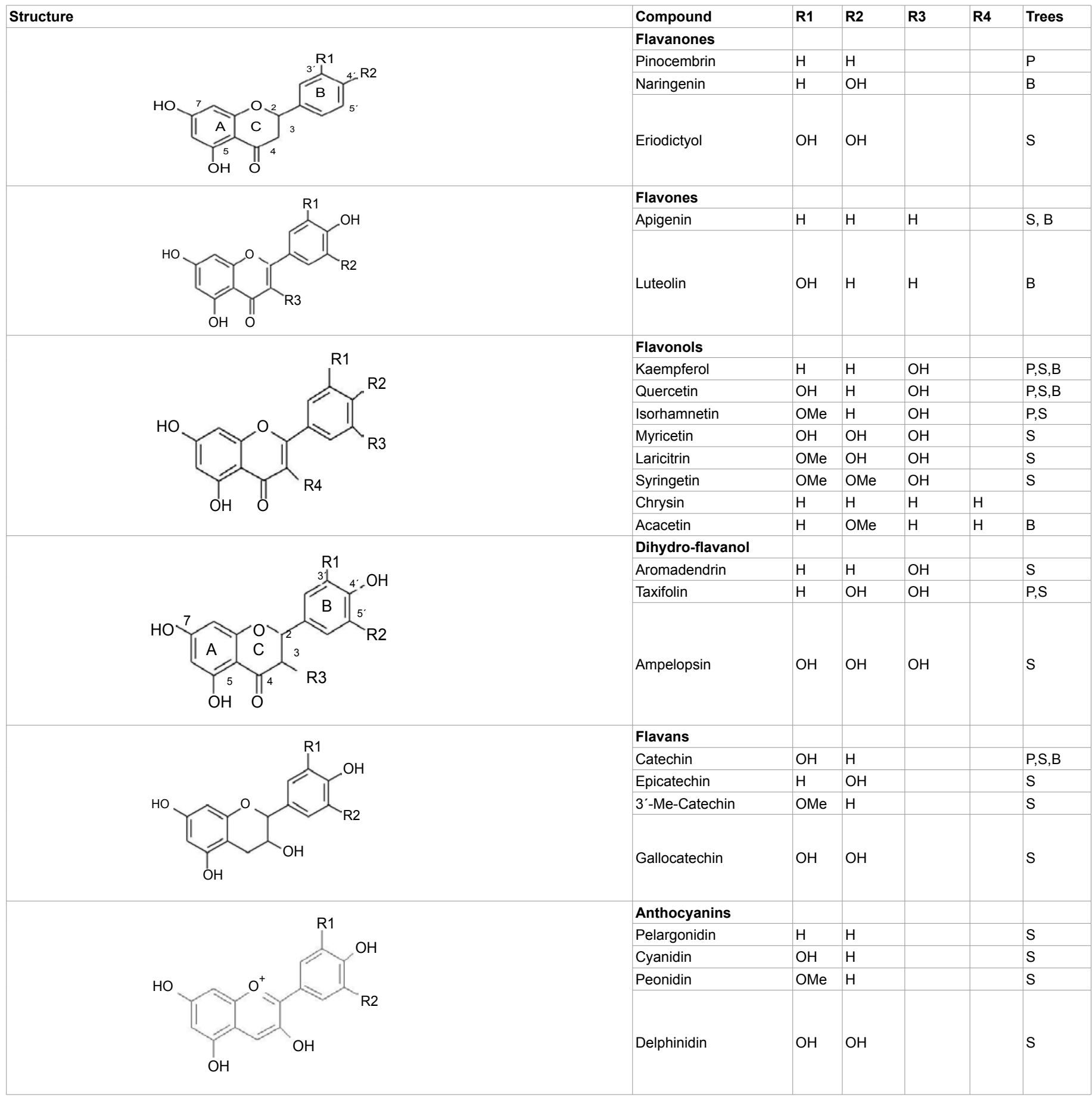

Table 4: Flavonoids found in extracts of Scots pine (S), Norway spruce (S) and silver birch (B).

The leaf extracts of white birch have been observed to inhibit clearly the growth of gram-positive bacteria S. aureus [54]. Omar et al. [23] found that the bark extract of Betula papyrifera was active against gram-positive bacteria S. aureus, Bacillus subtilis, Enterococcus faecalis and Mycobacterium phlei, whilst the wood extract showed activity only against $S$. aureus. None of the extracts inhibited growth of gram-negative pathogens E. coli, Pseudomonas aeruginosa, Salmonella typhimurium and Klebsiella pneumonia.

The growth of $S$. aureus was inhibited very effectively by quercetin, kaempferol and naringenin [32,54], whereas +/- -catechin and (+)-catechin were inactive against it. In addition, Tsuchiya et al. [19] observed the antibacterial activity of kaempferol and naringenin against methicillin-resistant $S$. aureus (MRSA).

\section{Essential Oils}

The primary constituents of the essential oils of conifers are terpenes [55] and when they contain additional elements, usually oxygen, they are termed terpenoids $[1,20]$. Monoterpenes are the most representative molecules constituting $90 \%$ of the essential oils [20]. Terpenes are derived through isoprenoid pathway in plants [21] and 
<smiles>COc1cc(C[C@@H]2C(=O)OC[C@H]2[C@H](O)c2ccc(O)c(OC)c2)ccc1O</smiles>

Hydroxymatairesino<smiles>COc1cc(C[C@@H](CO)[C@H](CO)Cc2ccc(O)c(OC)c2)ccc1O</smiles>

Secoisolariciresinol<smiles>COc1cc([C@H]2c3cc(O)c(OC)cc3C[C@H]2CO)ccc1O</smiles>

Isolariciresinol<smiles>COc1cc([C@@H]2OCC3C2CO[C@@H]3c2ccc(OCCO)c(OC)c2)ccc1O</smiles><smiles>COc1cc([C@@H](O)[C@@H]2COC[C@@H]2[C@H](O)c2ccc(O)c(OC)c2)ccc1O</smiles><smiles>COc1cc([C@@H]2OC[C@H](C(O)c3ccc(O)c(C)c3)[C@H]2CO)ccc1O</smiles>

Figure 2: Lignans and oligolignans found in hydrophilic knotwood extracts [29,31].

The leaf extracts of white birch have been observed to inhibit clearly the growth of gram-positive bacteria S. aureus [54]. Omar et al. [23] found that the bark extract of Betula papyrifera was active against gram-positive bacteria S. aureus, Bacillus subtilis, Enterococcus faecalis and Mycobacterium phlei, whilst the wood extract showed activity only against $S$. aureus. None of the extracts inhibited growth of gram-negative pathogens E. coli, Pseudomonas aeruginosa, Salmonella typhimurium and Klebsiella pneumonia.

The growth of S. aureus was inhibited very effectively by quercetin, kaempferol and naringenin [32,54], whereas $+/$ - -catechin and (+)-catechin were inactive against it. In addition, Tsuchiya et al. [19] observed the antibacterial activity of kaempferol and naringenin against methicillin-resistant $\mathrm{S}$. aureus (MRSA).

\section{Essential Oils}

The primary constituents of the essential oils of conifers are terpenes [55] and when they contain additional elements, usually oxygen, they are termed terpenoids $[1,20]$. Monoterpenes are the most representative molecules constituting 90\% of the essential oils [20]. Terpenes are derived through isoprenoid pathway in plants [21] and they are based on an isoprene structure (Figure 3). Different conifer species often contain the same terpenes but in different portions
[55] (Appendix 2). They can be obtained by expression, fermentation, extraction or by stream distillation that is the most commonly used method for commercial production of essential oils [56]. However, greater antibacterial activity has been observed with essential oils extracted by hexane than the corresponding steam distilled essential oils.

Essential oils of pine needles and spruce have been reported to be inactive against gram-negative bacteria but to have significant activities against gram-positive bacteria $S$. aureus, E. faecalis and $B$. subtilis, L. monocytogenes and Listeria ivanovii) [35,57] (Table 5). On the contrary, Hammer et al. [25] have noticed stronger activity against gram-negative $E$. coli than $S$. aureus.

Few studies have been published at the antimicrobial activity of terpenes present in conifer extracts. $\beta$-Pinene (from nutmeg) has been found to be particularly effective against E. coli O157:H7. Mourey and Canillac [55] studied activity of commercial terpenes, $\alpha$-pinene, $\beta$-pinene, 1,8-cineole, R-limonene, S-limonene and borneol, against L. monocytogenes serovars, which is one of the most dangerous food pathogens. The terpenes studied had a significant anti-Listeria activity (Table 5). $\alpha$-Pinene was the most active compound with an average MIC of 0.019-0.025\% against L. monocytogenes, while 1,8-cineole was the least inhibitory and had the lowest activity against bacteria being $0.375-0.417 \%$, although this concentration was directly bactericidal. 


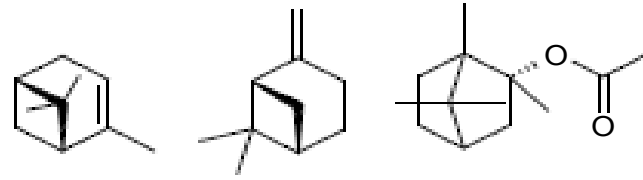

alpha-Pinene

beta-Pinene

Bomyl acetate<smiles>Cc1ccc(C(C)C)cc1</smiles><smiles>C1C2CC3CC1CC(C2)C3</smiles>

Tricyclene<smiles>C=C(C)[C@H]1CC=C(C)CC1</smiles><smiles>CC1CCCCC1(C)C</smiles><smiles>CC1=CCC(=C(C)C)CC1</smiles><smiles>CC1=CCC(C(C)C)C=C1</smiles>
p-Cymene<smiles>C=C1C=CC(C(C)C)CC1</smiles>

Limonene 1,8-Cineole Terpinolene

alpha-Phellandrene

beta-Phellandrene<smiles>CC1=CC[C@@H]2[C@H](C1)C2(C)C</smiles>

delta-3-Carene<smiles>CC1=CCC(C(C)C)=CC1</smiles>

gamma-Terpinene<smiles>C=CC(=C)CCC=C(C)C</smiles>

Myrcene<smiles>CC1=CCC(C(C)(C)O)CC1</smiles>

alpha-Terpineol<smiles>C=C1C2CCC(C2)C1(C)C</smiles>

Camphene<smiles>CC1=CCC(O)(C(C)C)CC1</smiles>

Terpinen-4-ol<smiles></smiles>

Fenchene Sabinene

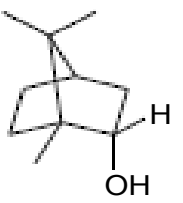

Bomeol

Figure 3: Structures of monoterpenes found in Scots pine and Norway spruce.

Furthermore, 1,8-cineole has exhibited low antibacterial activity against MRSA and vancomycin-resistant enterococci (VRE) E. faecalis [18].

Non-oxygenated monoterpene hydrocarbons, $\alpha$-pinene, p-cymene and $\gamma$-terpinene have shown the least antibacterial activity among essential oil components [58-60]. Furthermore, these compounds may produce antagonistic effects and therefore, lower the antimicrobial activity of essential oil. Terpinen-4-ol from tea tree oil has been active on its own against $P$. aeruginosa and $S$. aureus, but reduced efficacy has been observed in combination with either $\gamma$-terpinene or p-cymene due to lowered aqueous solubility [61]. Also minor components in essential oil may play a role in antibacterial activity of the main component as interactions between components may lead to additive, synergistic or antagonistic effects $[20,56]$.

\section{Mechanisms of Activity}

In general, the extracts were more active against gram-positive bacteria than gram-negative bacteria [23,28,58-66]. The main difference between gram-positive and gram-negative bacteria is the structure of their cell walls. Therefore it seems that the main target of the antibacterial activity is to destroy the cell walls of the bacteria. The gram-negative cell envelope is made up of lipopolysaccharide that renders the surface highly hydrophilic whereas the lipophilic structure of the cell membrane of gram-positive bacteria may facilitate penetration by hydrophobic compounds $[13,57,66]$. Thus, flavonoids and stilbenes with lower hydroxylation should be more active against bacteria than those with the several hydroxyl groups. However, there is no clear comparability between the degree of hydroxylation and toxicity to bacteria. Either the mechanism of action of terpenes is not fully understood but is speculated to involve membrane disruption by the lipophilic compounds $[1,67,68]$.

\section{Conclusions}

The extracts of Scots pine, Norway spruce, silver and white birches stem, bark, roots, leaves and needles contain several useful bioactive compounds that exhibit antibacterial activity against pathogens. Both phenolic extracts and essential oils are bacteriostatic against several bacteria. The main individual antibacterial phenolic compounds in Scots pine are pinosylvins that effectively inhibit growth of pathogens such as B. cereus, S. aureus and L. monocytogenes. From other phenolic compounds lignans appeared to be the least bacteriostatic and flavonoids tend to occur as glycosylated forms which have lower antibacterial activity than their aglycones. Gram-positive bacteria are generally more susceptible to plants bioactive compounds than gramnegative bacteria. 
Citation: Metsämuuronen S, Siren H (2014) Antibacterial Compounds in Predominant Trees in Finland: Review. J Bioprocess Biotech 4: 167 doi: 10.4172/2155-9821.1000167

Page 10 of 13

\begin{tabular}{|c|c|c|c|c|}
\hline Substance & Bacteria & Inhibitory effect, \% & & Ref. \\
\hline $\begin{array}{l}\text { Scots pine, } \\
\text { needles }\end{array}$ & $\begin{array}{l}\text { Escherichia coli } \\
\text { Pseudomonas aeruginosa } \\
\text { Proteus mirabilis } \\
\text { Klebsiella pneumoniae } \\
\text { Staphylococcus aureus } \\
\text { Staphylococcus aureus } \\
\text { Staphylococcus aureus } \\
\text { Enterococcus faecalis } \\
\text { Bacillus subtilis }\end{array}$ & $\begin{array}{l}\mathrm{MIC}>100 \mathrm{mg} \mathrm{L}^{-1} \\
\mathrm{MIC}>100 \mathrm{mg} \mathrm{L}^{-1} \\
\mathrm{MIC}>100 \mathrm{mg} \mathrm{L}^{-1} \\
\mathrm{MIC}>100 \mathrm{mg} \mathrm{L}^{-1} \\
\mathrm{MIC} 25 \mathrm{mg} \mathrm{L}^{-1} \\
\mathrm{MBC}>50 \mathrm{mg} \mathrm{L}^{-1} \\
\mathrm{MIC}>100 \mathrm{mg} \mathrm{L}^{-1} \\
\mathrm{MIC} 12.5 \mathrm{mg} \mathrm{L}^{-1} \\
\mathrm{MBC}>50 \mathrm{mg} \mathrm{L}^{-1} \\
\mathrm{MIC} 3.1 \mathrm{mg} \mathrm{L}^{-1} \\
\mathrm{MIC} 50 \mathrm{mg} \mathrm{L}^{-1}\end{array}$ & $\begin{array}{l}\text { Agar diffusion and } \\
\text { liquid dilution } \\
\text { methods }\end{array}$ & [35] \\
\hline $\begin{array}{l}\text { Scots pine, } \\
\text { needles }\end{array}$ & $\begin{array}{l}\text { Escherichia coli } \\
\text { Pseudomonas aeruginosa } \\
\text { Klebsiella pneumoniae } \\
\text { Staphylococcus aureus } \\
\text { Acinetobacter humanii } \\
\text { Aeromonas sobria } \\
\text { Enterococcus faecalis } \\
\text { Salmonella typhimurium } \\
\text { Serratia marcescens }\end{array}$ & $\begin{array}{l}\text { MIC } 2.0 \%(\mathrm{v} / \mathrm{v}) \\
M I C>2.0 \%(\mathrm{v} / \mathrm{v}) \\
M I C>2.0 \%(\mathrm{v} / \mathrm{v}) \\
M I C>2.0 \%(\mathrm{v} / \mathrm{v}) \\
M I C 2.0 \%(\mathrm{v} / \mathrm{v}) \\
M I C 2.0 \%(\mathrm{v} / \mathrm{v}) \\
M I C>2.0 \%(\mathrm{v} / \mathrm{v}) \\
M I C>2.0 \%(\mathrm{v} / \mathrm{v}) \\
M I C>2.0 \%(\mathrm{v} / \mathrm{v})\end{array}$ & $\begin{array}{l}\text { Agar dilution } \\
\text { method }\end{array}$ & [25] \\
\hline $\begin{array}{l}\text { Norway spruce, } \\
\text { essential oil } \\
\text { commercial }\end{array}$ & $\begin{array}{l}\text { Escherichia coli } \\
\text { Klebsiella pneumoniae } \\
\text { Klebsiella oxytoca } \\
\text { Enterobacter cloacae } \\
\text { Staphylococcus aureus } \\
\text { Listeria monocytogenes } \\
\text { Listeria ivanovii }\end{array}$ & $\begin{array}{l}>16 \% \\
\geq 16 \% \\
\geq 16 \% \\
\geq 16 \% \\
\text { MIC } 0.022-0.061 \% \text {, } \\
\text { MBC } 0.25 \% \\
\text { MIC } 0.015-0.067 \% \text {, } \\
\text { MBC } 0.20 \% \\
\text { MIC } 0.025 \% \\
\text { MBC } 0.27 \%\end{array}$ & Dilution & {$[57]$} \\
\hline a-Pinene & $\begin{array}{l}\text { Escherichia coli } \\
\text { Pseudomonas aeruginosa } \\
\text { Salmonella typhimurium } \\
\text { Yersinia enterocolitica } \\
\text { Staphylococcus aureus } \\
\text { Staphylococcus epidermis } \\
\text { Enterococcus faecalis } \\
\text { Bacillus cereus }\end{array}$ & $\begin{array}{l}\mathrm{MBC}>900 \mathrm{mg} \mathrm{L}^{-1} \\
\mathrm{MBC}>900 \mathrm{mg} \mathrm{L}^{-1} \\
\mathrm{MBC}>900 \mathrm{mg} \mathrm{L}^{-1} \\
\mathrm{MBC}>900 \mathrm{mg} \mathrm{L}^{-1} \\
\mathrm{MBC}>900 \mathrm{mg} \mathrm{L}^{-1} \\
\mathrm{MBC}>900 \mathrm{mg} \mathrm{L}^{-1} \\
\mathrm{MBC}>900 \mathrm{mg} \mathrm{L}^{-1} \\
\mathrm{MBC}>900 \mathrm{mg} \mathrm{L}^{-1}\end{array}$ & $\begin{array}{l}\text { Broth dilution, } \\
\text { visible growth }\end{array}$ & {$[58]$} \\
\hline & Listeria monocytogenes & $\begin{array}{l}\text { MIC } 0.019-0.025 \% \\
\text { MBC } 0.192-0.354 \%\end{array}$ & $\begin{array}{l}\text { Broth dilution, } \\
\text { visible growth }\end{array}$ & {$[55]$} \\
\hline & Several bacteria & No activity & $\begin{array}{l}\text { Vapour diffusion } \\
\text { test, } \\
\text { Agar test }\end{array}$ & {$[59,60]$} \\
\hline$\beta$-Pinene & Listeria monocytogenes & $\begin{array}{l}\text { MIC 0.041-0.060\%, } \\
\text { MBC 0.55-1.167\% }\end{array}$ & $\begin{array}{l}\text { Broth dilution, } \\
\text { visible growth }\end{array}$ & {$[55]$} \\
\hline R Limonene & Listeria monocytogenes & $\begin{array}{l}\text { MIC 0.047-0.062\%, } \\
\text { MBC 0.208-0.45\% }\end{array}$ & $\begin{array}{l}\text { Broth dilution, } \\
\text { visible growth }\end{array}$ & {$[55]$} \\
\hline S Limonene & Listeria monocytogenes & $\begin{array}{l}\text { MIC } 0.028-0.062 \% \\
\text { MBC } 0.15-0.45 \%\end{array}$ & $\begin{array}{l}\text { Broth dilution, } \\
\text { visible growth }\end{array}$ & {$[55]$} \\
\hline Borneol & Listeria monocytogenes & $\begin{array}{l}\text { MIC 0.039-0.094\%, } \\
\text { MBC } 0.039-0.156 \%\end{array}$ & $\begin{array}{l}\text { Broth dilution, } \\
\text { visible growth }\end{array}$ & {$[55]$} \\
\hline \multirow[t]{2}{*}{ 1,8-Cineole } & Listeria monocytogenes & $\begin{array}{l}\text { MIC 0.375-0.417\%, } \\
\text { MBC 0.375-0.417\% }\end{array}$ & $\begin{array}{l}\text { Broth dilution, } \\
\text { visible growth }\end{array}$ & {$[55]$} \\
\hline & $\begin{array}{l}\text { Escherichia coli } \\
\text { Pseudomonas aeruginosa } \\
\text { Klebsiella pneumoniae } \\
\text { Acinetobacter baumanii } \\
\text { Bacillus subtilis } \\
\text { Staphylococcus saprophyticus } \\
\text { Staphylococcus aureus, } \\
\text { MRSA } \\
\text { Staphylococcus epidermis } \\
\text { Staphylococcus agalactiae } \\
\text { Staphylococcus pyogenes } \\
\text { Enterococcus faecalis, VRE }\end{array}$ & $\begin{array}{l}\mathrm{MIC}>8 \mathrm{mg} \mathrm{mL}^{-1} \\
\mathrm{MIC}>8 \mathrm{mg} \mathrm{mL}^{-1} \\
\mathrm{MIC}>8 \mathrm{mg} \mathrm{mL}^{-1} \\
\mathrm{MIC} 8 \mathrm{mg} \mathrm{mL}^{-1} \\
\mathrm{MIC} 32 \mathrm{mg} \mathrm{mL}^{-1} \\
\mathrm{MIC}>8 \mathrm{mg} \mathrm{mL}^{-1} \\
\mathrm{MIC} 64 \mathrm{mg} \mathrm{mL}^{-1} \\
\mathrm{MIC}>8 \mathrm{mg} \mathrm{mL}^{-1} \\
\mathrm{MIC}>8 \mathrm{mg} \mathrm{mL}^{-1} \\
\mathrm{MIC} 16 \mathrm{mg} \mathrm{mL}^{-1} \\
\mathrm{MIC}>8 \mathrm{mg} \mathrm{mL}^{-1}\end{array}$ & $\begin{array}{l}\text { Broth } \\
\text { microdilution }\end{array}$ & [18] \\
\hline
\end{tabular}


Citation: Metsämuuronen S, Siren H (2014) Antibacterial Compounds in Predominant Trees in Finland: Review. J Bioprocess Biotech 4: 167 doi: 10.4172/2155-9821.1000167

Page 11 of 13

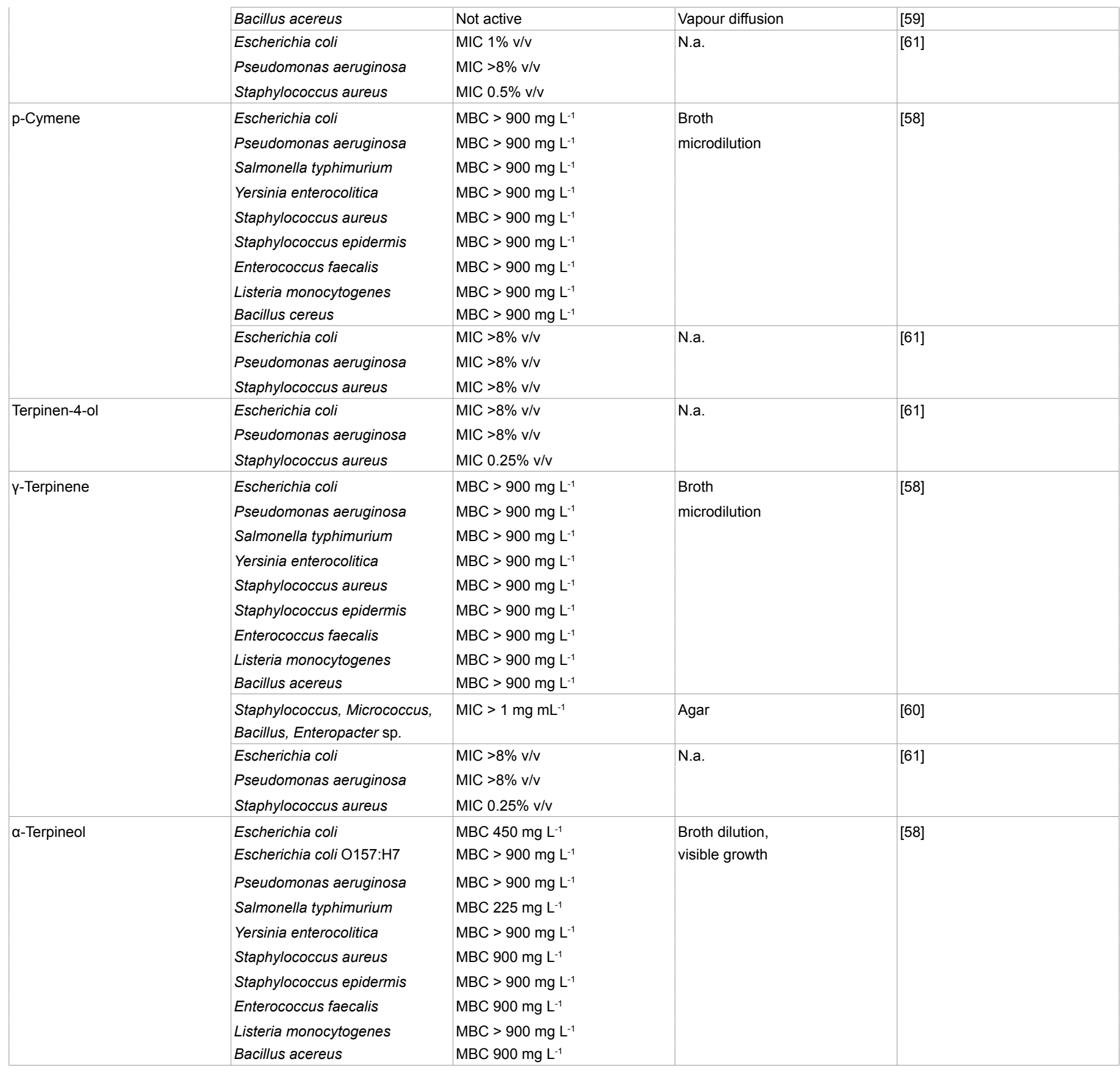

$\mathrm{Na} .=$ not announced

Table 5: Essential oils of conifers and pure monoterpenes and -terpenoids with their activity against selected bacteria.

\section{References}

1. Cowan MM (1999) Plant Products as Antimicrobial Agents. Clin Microbiol Rev 12: $564-582$

2. Bernhoft A (2008) A brief review on bioactive compounds in plants. Bioactive compounds in plants - benefits and risks for man and animals. The Notwegian Academy of Science and Letters, Oslo, Norway.

3. Pesewu GA, Cutler RR, Humber DP (2008) Antibacterial activity of plants used in traditional medicines of Ghana with particular reference to MRSA. J Ethnopharmacol 116: 102-111.

4. Ao C, Li A, Elzaawely AA, Xuan TD, Tawata S (2008) Evaluation of antioxidant and antibacterial activities of Ficus microcarpa L. fil. Extract. Food Control 19: 940-948.
5. Aremu AO, Ndhlala AR, Fawole OA, Light ME, Finnie JF, et al., (2010) In vitro pharmacological evaluation and phenolic content of ten South African medicinal plants used as anthelmintics. S Afr J Bot 76: 558-566.

6. Kumar VP, Chauhan NS, Padh H, Rajani M (2006) Search for antibacterial and antifungal agents from selected Indian medicinal plants. J Ethnopharmacol 107: $182-188$

7. Navarro V, Villarreal ML, Rojas G, Lozoya X (1996) Antimicrobial evaluation of some plants used in Mexican traditional medicine for the treatment of infectious diseases. J Ethnopharmacol 53: 143-147.

8. Ahmad I, Beg AZ (2001) Antimicrobial and phytochemical studies on 45 Indian medicinal plants against multi-drug resistant human pathogens. J Ethnopharmacol 74: 113-123. 
Citation: Metsämuuronen S, Siren H (2014) Antibacterial Compounds in Predominant Trees in Finland: Review. J Bioprocess Biotech 4: 167 doi: 10.4172/2155-9821.1000167

Page 12 of 13

9. Maregesi SM, Pieters L, Ngassapa OD, Apers S, Vingerhoets R, et al., (2008) Screening of some Tanzanian medicinal plants from Bunda district for antibacterial, antifungal and antiviral activities. J Ethnopharmacol 119: 58-66.

10. Jagtap UB, Bapat VA (2010) Artocarpus: A review of its traditional uses, phytochemistry and pharmacology. J Ethnopharmacol 129: 142-166.

11. Cassidy A, Hanley B, Lamuela-Raventos RM (2000) Isoflavones, lignans and stilbenes - origins, metabolism and potential importance to human health. J Sci Food Agric 80: 1044-1062.

12. Stevanovic T, Diouf PN, Garcia-Perez ME (2009) Bioactive Polyphenols from Healthy Diets and Forest Biomass. Current Nutrition \& Food Science 5: 264295.

13. Takahashi T, Kokubo R, Sakaino M (2004) Antimicrobial activities of eucalyptus leaf extracts and flavonoids from Eucalyptus maculate. Lett Appl Microbiol 39 : 60-64.

14. Tohidpour, Sattari M, Omidbaigi R, Yadegar A, J Nazemi (2010) Antibacterial effect of essential oils from two medicinal plants against Methicillin-resistant Staphylococcus aureus (MRSA). Phytomedicine 17: 142-145.

15. Adugna B, Terefe G, Kebede N (2014) Potential In vitro Anti-Bacterial Action of Selected Medicinal Plants Against Escherichia coli and Three Salmonella Species. International Journal of Microbiological Research 5: 85-89.

16. Essawi T, Srour M (2000) Screening of some Palestinian medicinal plants for antibacterial activity. J Ethnopharmacol 70: 343-349.

17. Chang S, Chen P, Chang S (2001) Antibacterial activity of leaf essential oils and their constituents from Cinnamomum osmophloeum. J Ethnopharmacol 77: 123-157.

18. Mulyaningsih S, Sporer F, Zimmermann S, Reichling J, Wink M (2010) Synergistic properties of the terpenoids aromadendrene and 1,8-cineole from the essential oil of Eucalyptus globulus against antibiotic-susceptible and antibiotic-resistant pathogens. Phytomedicine 17: 1061-1066.

19. Tsuchiya H, Sato M, Miyazaki T, Fujiwara S, Tanigaki S, et al., (1996) Comparative study on the antibacterial activity of phytochemical flavanones against methicillin-resistant Staphylococcus aureus. J Ethnopharmacol 50: 2734.

20. Bakkali F, Averbeck S, Averbeck D, Idaomar M (2008) Biological effects of essential oils - A review. Food and Chemical Toxicology 46: 446-475.

21. Iriti M, Faoro F (2009) Chemical Diversity and Defence Metabolism: How Plants Cope with Pathogens and Ozone Pollution. Int J Mol Sci 10: 3371-3399.

22. Rice-Evans CA, Miller NJ, Paganga G (1996) Structure-antioxidant activity relationships of flavonoids and phenolic acids. Free Radic Biol Med 20: 933956

23. Omar S, Lemonnier B, Jones N, Ficker C, Smith ML, et al., (2000) Antimicrobia activity of extracts of eastern North American hardwood trees and relation to traditional medicine. J Ethnopharmacol 73: 161-170.

24. Omar S, Lalonde M, Marcotte M, Cook M, Proulx J, et al., (2000) Insect growthreducing and antifeedant activity in Eastern North America hardwood species and bioassay-guided isolation of active principles from Prunus serotina. Agricult for Entomol 2: 253-257.

25. Hammer KA, Carson CF, Riley TV (1999) Antimicrobial activity of essential oils and other plant extracts. J Appl Microbiol 86: 985-990.

26. Venäläinen $M$, Harju AM, Saranpää $P$, Kainulainen $P$, Tiitta $M$, et al., (2004) The concentration of phenolics in brown-rot decay resistant and susceptible Scots pine heartwood. Wood Sci Technol 38: 109-118.

27. Harju, Venäläinen $M$, Anttonen S, Viitanen H, Kainulainen P, et al., (2003) Chemical factors affecting the brown-rot decay resistance of Scots pine heartwood. Trees 17: 263-268.

28. Lindberg LE, Willför SM, Holmbom BR (2004) Antibacterial effects of knotwood extractives on paper mill bacteria. Journal of Industrial Microbiology \& Biotechnology 31: 137-147

29. Willför SM, Ahotupa MO, Hemming JE, Reunanen MHT, Eklund PC, et al., (2003) Antioxidant Activity of Knotwood Extractives and Phenolic Compounds of Selected Tree Species. J Agric Food Chem 51: 7600-7606.

30. Välimaa, Honkalampi-Hämäläinen U, Pietarinen S, Willför S, Holmbom B, et al., (2007) Antimicrobial and cytotoxic knotwood extracts and related pure compounds and their effects on food-associated microorganisms. Int $\mathrm{J}$ Food
Microbiol 115: 235-243.

31. Pietarinen SP, Willför SM, Ahotupa MO, Hemming JE, Holmbom BR (2006) Knotwood and bark extracts: strong antioxidants from waste materials. Journa of Wood Science 52: 436-444.

32. Rauha J, Remes S, Heinonen M, Hopia A, Kähkönen M, et al., (2000) Antimicrobial effects of Finnish plant extracts containing flavonoids and other phenolic compounds. Int J Food Microbiol 56: 3-12.

33. Karonen M, Hämäläinen M, Nieminen R, Klika KD, Loponen J, et al., (2004) Phenolic Extractives from the Bark of Pinus sylvestris L. and Their Effects on Inflammatory Mediators Nitric Oxide and Prostaglandin E2. J Agric Food Chem 52: $7532-7540$.

34. Kähkönen MP, Hopia Al, Vuorela HJ, Rauha J, Pihlaja K, et al., (1999) Antioxidant Activity of Plant Extracts Containing Phenolic Compounds. J Agric Food Chem 47: 3954-3962.

35. Kartnig T, Still F, Reinthaler F (1991) Antimicrobial activity of the essential oil of young pine shoots (Picea abies L.). J Ethnopharmacol 35: 155-157.

36. Zeneli G, Krokene P, Christiansen E, Krekling T, Gershenzon J (2006) Methy jasmonate treatment of mature Norway spruce (Picea abies) trees increases the accumulation of terpenoid resin components and protects against infection by Ceratocystis polonica, a bark beetle-associated fungus. Tree Physiol 26 977-988.

37. Viiri H, Annila E, Kitunen V, Niemelä P (2001) Induced responses in stilbenes and terpenes in fertilized Norway spruce after inoculation with blue-stain fungus, Ceratocystis polonica. Trees 15: 112-122.

38. Lieutier F, Brignolas F, Sauvard D, Yart A, Galet C, et al., (2003) Intra- and interprovenance variability in phloem phenols of Picea abies and relationship to bark beetle-associated fungus. Tree Physiol 23: 247-256.

39. http://www.academia.edu/741832/Phenolic_compounds_in_different_parts_ of_fir

40. Pan $\mathrm{H}$, Lundgren LN (1995) Phenolic extractives from root bark of Picea abies. Phytochemistry 42: 1423-1428.

41. Hovelstad H, Leirset I, Oyaas K, Fiksdahl A (2006) Screening Analyses of Pinosylvin Stilbenes, Resin Acids and Lignans in Norwegian Conifers. Molecules 11: 103-114.

42. Li SH, Niu XM, Zahn S, Gershenzon J, Weston J, et al., (2008) Diastereomeric stilbene glucoside dimers from the bark of Norway spruce (Picea abies) Phytochemistry 69: 772-782.

43. Puupponen-Pimiä R, Nohynek L, Meier C, Kähkönen M, Heinonen M, et al. (2001) Antimicrobial properties of phenolic compounds from berries. J Appl Microbiol 90: 494-507.

44. Baurhoo B, Ruiz-Feria CA, Zhao X (2008) Purified lignin: Nutritional and health impacts on farm animals-A review. Anim Feed Sci Technol 144: 175-184

45. Shan B, Cai YZ, Brooks JD, Corke H (2007) The in vitro antibacterial activity of dietary spice and medicinal herb extracts. Food Chem 117: 112-119.

46. Ibewuike JC, Ogungbamila FO, Ogundaini AO, Okeke IN, Bohlin L (1997) Antiinflammatory and antibacterial activities of C-methylflavonols from Piliostigma thonningii. Phytother Res 11: 281-284.

47. Ji Y, Zhou Y (2013) Mathematical Modelling of Protein Precipitation Based on the Phase Equilibrium for an Antibody Fragment from E. coli Lysis. J Bioprocess Biotech 3: 129

48. Beninger CW, Abou-Zaid MM, Kistner ALE, Hallett RH, Iqbal MJ, et al., (1997) A Flavanone and Two Phenolic Acids from Chrysanthemum morifolium with Phytotoxic and Insect Growth Regulating Activity. Journal of Chemical Ecology 30: 589-606.

49. Eklund PC, Willför SM, Smeds AI, Sundell FJ, Sjöholm RE, et al., (2004) A New Lariciresinol-Type Butyrolactone Lignan Derived from Hydroxymatairesinol and Its Identification in Spruce Wood. J Nat Prod 67: 927-931.

50. Malá J, Hrubcová M, Máchová P, Cvrcková H, Martincová O, et al., (2011) Changes in phenolic acids and stilbenes induced in embryogenic cell cultures of Norway spruce by two fractions of Sirococcus strobilinus mycelia. J For Sci 57: 1-7.

51. Münzenberger B, Heilemann J, Strack D, Kottke I, Oberwinkler F (1990) Phenolics of mycorrhizas and non-mycorrhizal roots of Norway spruce. Planta 182: $142-148$ 
Citation: Metsämuuronen S, Siren H (2014) Antibacterial Compounds in Predominant Trees in Finland: Review. J Bioprocess Biotech 4: 167 doi: 10.4172/2155-9821.1000167

52. Slimestad R, Hostettmann K (1996) Characterisation of Phenolic Constituents from Juvenile and Mature Needles of Norway Spruce by Means of High Performance Liquid Chromatography-Mass Spectrometry. Phytochem Anal 7 : 42-48.

53. Ossipov V, Nurmi K, Loponen J, Prokopiev N, Haukioja E, et al. (1995) HPLC isolation and identification of flavonoids from white birch Betula pubescens leaves. Biochem Syst Ecol 23: 213-222.

54. Chu X, Zhen Z, Tang Z, Zhuang Y, Chu J, et al.(2012) Introduction of Extra Copy of Oxytetracycline Resistance Gene otrB Enhances the Biosynthesis of Oxytetracycline in Streptomyces rimosus. J Bioprocess Biotechniq 2: 117.

55. Mourey A, Canillac N (2002) Anti-Listeria monocytogenes activity of essential oils components of conifers. Food Control 13: 289-292.

56. Burt C (2004) Essential oils: their antibacterial properties and potential applications in foods-a review Int. J Food Microbiol 94: 223-253.

57. Canillac N, Mourey A (2001) Antibacterial activity of the essential oil of Picea excelsa on Listeria, Staphylococcus aureus and coliform bacteria. Food Microbiol 18: 261-268.

58. Cosentino S, Tuberoso CIG, Pisano B, Satta M, Mascia V, et al. (1999) In-vitro antimicrobial activity and chemical composition of Sardinian Thymus essential oils. Lett Appl Microbiol 29: 130-135.

59. López P, Sánchez C, Batlle R, Nerín C (2007) Vapor-Phase Activities of Cinnamon, Thyme, and Oregano Essential Oils and Key Constituents against Foodborne Microorganisms. J Agric Food Chem 55: 4348-4356.

60. Moleyar V, Narasimham P (1992) Antibacterial activity of essential oil components. Int J Food Microbiol 16: 337-342.
61. Cox SD, Mann CM, Markham JL (2001) Interactions between components of the essential oil of Melaleuca alternifolia. J Appl Microbiol 91: 492-497.

62. Takikawa A, Keiko A, Yamamoto M, Ishimaru S, Yasui M, et al. (2002) Antimicrobial activity of Nutmeg against Escherichia coli O157. Journal of Bioscience and Bioengineering 94: 315-320.

63. Cimanga K, Kambu K, Tona L, Apers S, De Bruyne T, et al., (2002) Correlation between chemical composition and antibacterial activity of essential oils of some aromatic medicinal plants growing in the Democratic Republic of Congo. J Ethnopharmacol 79: 213-220.

64. Eyles A, Davies NW, Mohammed C (2003) Novel Detection of Formylated Phloroglucinol Compounds (FPCs) in the Wound Wood of Eucalyptus globulus and E. nitens. Journal of Chemical Ecology 29: 881-898.

65. Gilles M, Zhao J, Min A, Agboola S (2010) Chemical composition and antimicrobial properties of essential oils of three Australian Eucalyptus species. Food Chem 119: 731-737.

66. Tyagi AK, Malik A (2011) Antimicrobial potential and chemical composition of Eucalyptusglobulus oil in liquid and vapour phase against food spoilage microorganisms. Food Chem 126: 228-235.

67. Cox SD, Mann CM, Markham JL, Bell HC, Gustafson JE, et al., (2000) The mode of antimicrobial action of the essential oil of Melaleuca alternifolia (tea tree oil). J Appl Microbiol 88: 170-175

68. Lambert RJW, Skandamis PN, Coote PJ, Nychas GE (2001) A study of the minimum inhibitory concentration and mode of action of oregano essential oil, thymol and carvacrol. J Appl Microbiol 91: 453-462. 